\title{
Hubungan Antara Motivasi Kerja terhadap Produktivitas Kerja Karyawan Pada BPJS Ketenagakerjaan Kota Depok
}

\author{
Nurlaela Eva Puji Lestari \\ Universitas Bina Sarana Informatika \\ e-mail: nurlaela.nep@bsi.ac.id
}

\begin{abstract}
Human resources in a company are the main factors so that the company can remain superior. Managing employees is not only by giving a job description given to them, but there needs to be a positive relationship between the company and employees to achieve a common goal. Motivation is one way for employees to be productive and energized in completing work. Basically motivation is the right of employees and is an obligation for the company to support employees so that employees can further increase the volume and quality of work that is the responsibility. Productivity is important for a company organization that is engaged in the production of goods and services. In general productivity is a comparison between results (output) with input (input). Samples were taken using saturated sampling where all employees at BPJS Employment in Depok City became respondents, as many as 34 respondents. The purpose of this study was to find out and analyze the relationship between Work Motivation (X) Against Employee Work Productivity (Y) at BPJS Employment in Depok City. Based on the analysis and processing of data based on the calculation of the correlation coefficient it can be seen that work motivation has a strong relationship that is equal to 0.795 and according to the calculation results the coefficient of determination can be known that is quite large, $63.2 \%$, so the relationship between work motivation $(X)$ and employee work productivity $(Y)$ it can be concluded that there is a strong relationship.
\end{abstract}

Keywords: Work Motivation, Employee Work Productivity

\section{PENDAHULUAN}

Motivasi merupakan salah satu cara agar karyawan dapat produktif dan berenergi dalam menyelesaikan pekerjaan.

Perkembangan dalam dunia bisnis saat ini sangat pesat dan persaingan semakin ketat sehingga setiap perusahaan harus menghadapi tantangan yang menuntut sumber daya manusia memiliki kualitas dan potensi yang berkembang agar mampu membawa pencapaian dalam perusahaan. Karyawan yang berkualitas rendah akan menghasilkan pencapaian yang kurang maksimal. Sumber daya manusia dalam suatu perusahaan merupakan faktor utama agar perusahaan dapat tetap unggul. Mengelola karyawan tidak hanya dengan memberikan deskripsi pekerjaan yang diberikan kepada mereka, tetapi perlu adanya hubungan yang positif antara perusahaan dengan karyawan untuk mencapai tujuan bersama.

Pada dasarnya pemberian motivasi adalah hak para karyawan dan merupakan kewajiban bagi pihak perusahaan untuk mendukung karyawan agar para karyawan dapat lebih meningkatkan volume dan mutu pekerjaan yang menjadi tanggung jawab. Perusahaan harus memperhatikan karyawannya dengan memberikan motivasi, karyawan dapat melaksanakan tugasnya secara maksimal antara lain ditentukan oleh motivasi yang mendorong karyawan tersebut untuk bekerja dengan tekun sehingga tercapai tujuan perusahaan. Terkadang masih banyak karyawan yang belum tentu bersedia mengerahkan potensi kerja yang mereka miliki secara maksimal, sehingga masih diperlukan adanya dorongan agar seseorang mau bekerja secara optimal.

Produktivitas merupakan hal yang penting bagi suatu organisasi perusahaan baik itu yang bergerak di bidang produksi barang maupun jasa. Secara umum produktivitas adalah perbandingan antara output (hasil) dengan input (masukan). Adanya produktivitas karyawan yang memadai akan dapat membantu upaya perusahaan dalam rangka mengembangkan usaha. Peningkatan produktivitas selama ini lebih banyak dilakukan melalui peningkatan pengetahuan dan keterampilan. Padahal bukan hanya itu saja, melainkan motivasi perlu untuk menunjang produktivitas kerja karyawan.

Badan penyelenggaraan jaminan sosial ketenagakerjaan (BPJSTK) merupakan perusahaan yang bergerak di bidang asuransi yang termasuk program publik dengan memberikan perlindungan bagi tenaga kerja untuk mengatasi risiko sosial ekonomi tertentu dan penyelenggaraannya menggunakan mekanisme asuransi sosial. Sebelumnya, Badan Penyelenggaraan Jaminan Sosial Ketenagakerjaan (BPJSTK) bernama jamsostek (jaminan sosial tenaga kerja) yang dikelola oleh PT Jamsostek (persero). Kemudian pada tanggal 1 Januari 2014 PT Jamsostek berubah menjadi BPJS Ketenagakerjaan.

Berdasarkan penjelasan diatas, maka peneliti bermaksud untuk melakukan penelitian yang berjudul "Hubungan Antara Motivasi Kerja Terhadap Produktivitas Kerja Karyawan pada BPJS Ketenagakerjaan Kota Depok”. 


\section{Pengertian Motivasi}

Menurut (Sutrisno, 2016) mengemukakan bahwa "Motivasi adalah suatu faktor yang mendorong seseorang untuk melakukan suatu aktifitas tertentu". Kemudian menurut (Mangkunegara, 2015) "Motivasi adalah kondisi yang menggerakan pegawai agar mampu mencapai tujuan dari motifnya".

Sedangkan menurut Serdamayanti dalam (Ainnisya \& Susilowati, 2018) "Motivasi adalah kekuatan kecenderungan seorang individu melibatkan diri dalam kegiatan yang berarahkan sasaran dalam pekerjaan. Ini bukan perasaan senang yang relatif terhadap hasil berbagai pekerjaan sebagaimana halnya kepuasan, tetapi lebih merupakan perasaan sedia/rela bekerja untuk mencapai tujuan pekerjaan". Dan menurut Samsudin dalam (Lestari, 2018) "Motivasi kerja adalah sesuatu yang menimbulkan dorongan atau semangat kerja yang dipengaruhi oleh beberapa faktor, antara lain atasan, sarana fisik, kebijaksanaan, peraturan, imbalan jasa uang dan non uang, jenis pekerjaan dan tantangan".

\section{Tujuan Pemberian Motivasi}

Menurut (Hasibuan, 2016) mengemukakan beberapa tujuan pemberian motivasi adalah sebagai berikut:

1. Mendorong gairah dan semangat karyawan

2. Meningkatkan moral dan kepuasan kerja karyawan

3. Meningkatkan produktivitas kerja karyawan

4. Mempertahankan loyalitas karyawan dan kestabilan karyawan perusahaan

5. Meningkatkan kedisiplinan dan menurunkan tingkat absensi karyawan

6. Mengefektifkan pengadaan karyawan

7. Mendapatkan suasana dan hubungan kerja yang baik

8. Meningkatkan kreativitas dan partisipasi karyawan

9. Mempertinggi rasa tanggung jawab karyawan terhadap tugas-tugasnya

10. Meningkatkan efisiensi penggunaan alat-alat dan bahan baku

\section{Bentuk-Bentuk Motivasi}

Menurut (Siswanto, 2014) bentuk motivasi yang sering dianut oleh perusahaan meliputi empat elemen utama, yaitu sebagai berikut:

1. Kompensasi Bentuk Uang

Salah satu bentuk yang paling sering diberikan kepada karyawan adalah berupa kompensasi. Kompensasi sebagai kekuatan untuk memberi motivasi selalu mempunyai reputasi atau nama baik dan memang sudah selayaknya demikian. Sebenarnya pemberian kompensasi bentuk uang sebagai motivasi kerja para karyawan memiliki dua pengaruh perilaku. Keanggotaan adalah pengaruh yang paling luas, yang mempengaruhi karyawan pada semua tingkat pendapatan. Pengaruh yang kedua adalah negatif, dari sudut pandang perusahaan, dan cenderung terbatas hanya pada karyawan yang pendapatannya tidak lebih dari tingkat standar kehidupan yang layak dan cenderung menganggap kompensasi bentuk uang sebagai tidak seimbang.

2. Pengarahan dan Pengendalian

Pengarahan dimaksudkan menentukan bagi karyawan mengenai apa yang harus mereka kerjakan dan apa yang tidak mereka kerjakan. Sedangkan pengendalian dimaksudkan menentukan karyawan harus mengerjakan hal-hal yang telah diinstuksikan.

3. Penetapan Pola Kerja yang Efektif

Pada umumnya reaksi terhadap kebosanan kerja menimbulkan hambatan yang berarti bagi keluaran produktivitas kerja. Karena manajemen menyadari bahwa masalahnya bersumber pada cara pengaturan pekerjaan, mereka menanggapinya dengan berbagai teknik yang efektif dan kurang efektif.

4. Kebijakan

Kebijakan dapat didefinisikan sebagai suatu tindakan yang diambil dengan sengaja oleh manajemen untuk mempengaruhi sikap atau perasaan karyawan. Dengan kata lain, kebijakan adalah usaha untuk membuat karyawan bahagia.

\section{Faktor-Faktor Yang Mempengaruhi Motivasi}

Faktor-faktor motivasi kerja yang penulis gunakan dalam penelitian ini menurut Maslow dalam (Sutrisno, 2016) mengemukakan hal-hal yang mempengaruhi motivasi, yaitu:

1. Kebutuhan Fisiologis (physiological)

Kebutuhan untuk mempertahankan hidup. Kebutuhan ini merupakan tingkat yang paling dasar berupa kebutuhan akan makan, minum, perumahan, pakaian, dan sebagainya yang harus dipenuhi oleh seseorang.

2. Kebutuhan rasa aman (safety)

Kebutuhan akan rasa aman dan keselamatan. Kebutuhan ini akan dirasakan mendesak setelah kebutuhan pertama terpenuhi.

3. Kebutuhan hubungan sosial (affiliation)

Kebutuhan ini merupakan kebutuhan untuk hidup bersama orang lain, seperti butuh akan kasih sayang, dicintai, dihormati, dan diikut sertakan dalam pergaulan.

4. Kebutuhan pengakuan (esteem)

Kebutuhan adanya pengahargaan diri dan penghargaan prestasi diri dari lingkungannya. Semakin tinggi status dan kedudukan seseorang dalam perusahaan, maka semakin tinggi pula kebutuhan akan prestasi diri yang bersangkutan.

5. Kebutuhan aktualisasi diri (self actualization) Kebutuhan aktualisasi diri merupakan tingkat kebutuhan yang paling tinggi. Untuk memenuhi kebutuhan puncak ini biasanya seseorang bertindak bukan atas dorongan orang lain, tetapi karena kesadaran dan keinginan diri sendiri. 


\section{Alat-alat dan Jenis-jenis Motivasi}

Menurut (Hasibuan, 2016) alat-alat motivasi terdiri atas:

1. Materiil Insentif: alat motivasi yang diberikan berupa uang dan atau barang yang mempunyai nilai pasar; jadi memberikan kebutuhan ekonomis. Misalnya: kendaraan, rumah dan lain - lainnya.

2. Nonmaterial Insentif: alat motivasi yang diberikan berupa barang atau benda yang tidak ternilai; jadi hanya memberikan kepuasaan atau kebanggaan rohani saja. Misalnya: medali, piagam, bintang jasa dan lain-lainnya.

3. Kombinasi Materill dan Nonmateriil Insentif: alat motivasi yang diberikan berupa materiil (uang dan barang) dan nonmaterial (medali dan piagam); jadi memenuhi kebutuhan ekonomis dan kepuasan atau kebanggaan rohani.

Menurut Hasibuan (2010:99) Jenis-jenis motivasi yaitu:

1. Motivasi Positif (Insentif Positif), manajer memotivasi bawahan dengan memberikan hadiah kepada mereka yang berprestasi baik. Dengan motivasi positif ini semangat kerja bawahannya akan meningkat, karena manusia pada umumnya senang menerima yang baik-baik saja.

2. Motivasi Negatif (Insentif negatif), manajer memotivasi bawahannya dengan memberikan hukuman kepada mereka yang pekerjaannya kurang baik (prestasi rendah). Dengan memotivasi negatif ini semangat kerja bawahan dalam jangka pendek akan meningkat, karena mereka takut di hukum; tetapi untuk jangka waktu panjang dapat berakibat kurang baik.

\section{Produktivitas}

Menurut Hasibuan (2016:126) mengemukakan "Produktivitas adalah perbandingan antara output (hasil) dengan input (masukan). Jika produktivitas naik ini hanya dimungkinkan oleh adanya peningkatan efisiensi (waktu-bahan-tenaga) dan sistem kerja, teknik produksi dan adanya peningkatan keterampilan dari tenaga kerjanya".

Sedangkan menurut Siagian dalam Sutrisno (2016:99) "Peningkatan produktivitas kerja hanya mungkin dilakukan oleh manusia. Sebaliknya, sumber daya manusia pula yang dapat menjadi penyebab terjadinya pemborosan dan inefisien dalam berbagai bentuknya".

Menurut Hakim dalam (Hanif, 2018) "Jika produktivitas rendah, ini berarti perusahaan kurang maksimal dalam menggunakan tenaga kerjanya, sehingga keluaran yang dihasilkan tidak sepadan dengan biaya yang ditanggung”.

Menurut Hartatik (2014:209) mengungkapkan bahwa "Produktivitas adalah kemampuan menghasilkan barang dan jasa dari berbagai sumber daya atau faktor produksi yang digunakan untuk meningkatkan kualitas dan kuantitas pekerjaan yang dihasilkan dalam suatu perusahaan".

\section{Sumber-Sumber Produktivitas}

Manusia sebagai tenaga kerja harus mampu mendayagunakan sumber kerja, baik yang terdapat pada dirinya maupun lingkungan sekitarnya. Menurut Nawawi dan Martini Hadari dalam (Widodo, 2015) terdapat 5 sumber kerja yang merupakan sumber produktivitas yaitu:

1. Penggunaan Pikiran

Produktivitas kerja dikatakan tinggi apabila untuk memperoleh hasil yang maksimal dipergunakan cara bekerja yang paling mudah.

2. Penggunaan Tenaga Jasmani atau Fisik Produktivitas kerja dikatakan tinggi bilamana mengerjakan sesuatu diperoleh hasil dan jumlahnya terbanyak dan mutunya terbaik dengan tidak banyak menggunakan tenaga jasmani atau rohani.

3. Penggunaan Waktu

Semakin singkat jangka waktu yang dipergunakan untuk mencapai hasil terbanyak dan terbaik, menunjukkan semakin produktif pelaksanaan suatu pekerjaan.

4. Penggunaan ruangan

Pekerjaan akan produktif apabila sejumlah personel yang bekerja sama dalam melaksanakan pekerjaan ditempatkan dalam suatu ruangan yang berdekatan jaraknya untuk mondar-mandir lebih hemat.

5. Penggunaan Material atau Bahan Uang

Suatu pekerjaan dikatakan produktif jika penggunaan penggunaan bahan atau material dan peralatannya tidak terlalu banyak yang terbuang dan harganya tidak terlalu mahal.

\section{Jenis-jenis Produktivitas}

Jenis produktivitas menurut Nawawi dan Martini Hadari dalam (Nurmalasari, 2016) terdapat 3 jenis produktivitas yaitu, sebagai berikut:

1. Produktivitas Internal

Produktivitas internal adalah tingkat pencapaian target mengenai sesuatu yang harus dihasilkan sebagai keluaran (output) yang direncanakan selama jangka waktu tertentu.

2. Produktivitas Eksternal

Produktivitas eksternal adalah tingkat pendayagunaan atau kemanfaatan hasil yang dicapai suatu organisasi oleh masyarakat khususnya dilingkungan lapangan kerja.

3. Produktivitas Individu dan Kelompok Kerja Hasil yang menggambarkan produktivitas bersumber dan kemampuan personel secara individu dalam bekerja. Produktivitas juga dapat diartikan sebagai tingkat efisiensi dalam memproduksi barang-barang atau jasa-jasa. 
Faktor-faktor yang Mempengaruhi Produktivitas Untuk meningkatkan produktivitas kerja seseorang banyak faktor yang mempengaruhinya. Menurut (Mulyadi, 2015) faktor yang mempengaruhi produktivitas, yaitu:

1. Tingkat pendidikan

Tingkat pendidikan biasanya dengan tingkat pendidikan yang tinggi orang atau pekerja akan mudah dimotivasi untuk menyelesaikan pekerjaannya, sehingga dalam menyelesaikan tugasnya akan mudah untuk meningkatkan produktivitas kerjanya.

2. Kemampuan bekerja

kemampuan seseorang dalam menyelesaikan pekerjaannya, ia tidak mengalami kesulitan maka akan lebih cepat dan tepat untuk menyelesaikan tugasnya dengan kata lain bisa meningkatkan produktivitas kerjanya.

3. Skill atau keterampilan

Karyawan atau pekerja yang mempunyai skill atau keterampilan yang dimiliki, maka akan termotivasi untuk meningkatkan produktivitas.

4. Etika kerja

Sikap seseorang dalam menjalankan tugasnya dan sikap pimpinan yang baik dalam organisasi atau perusahaan itu maka karyawan atau pekerja akan termotivasi untuk meningkatkan produktivitas.

5. Motivasi (dorongan)

Dengan dimotivasi dari pimpinan atau termotivasi dari diri sendiri karyawan tersebut akan selalu meningkatkan produktivitas.

6. Jaminan kesehatan

Karyawan atau pekerja mendapatkan jaminan kesehatan yang baik dari perusahaan maka pekerja akan merasa nyaman dalam melaksanakan tugasnya, sehingga karyawan tersebut dengan sendirinya akan semangat atau meningkatkan produktivitas kerjanya.

7. Lingkungan kerja yang nyaman

Hubungan industial antara atasan dengan bawahan, atasan dengan atasan, dan karyawan dengan karyawan menunjukkan adanya hubungan industrial yang baik selalu berkomunikasi dengan baik, dan didukung dengan lingkungan kerja yang bersifat fisik semua akan mendukunga untuk meningkatkan produktivitas karayawan.

8. Sarana dan prasarana pendukunga produksi Apabila semua sarana dan prasarana pendukung produksi tersedia dengan baik dan mudah untuk dicari maka karyawan akan merasa mudah menjalankan tugasnya. Tetapi sebalikanya, apabila semua itu tidak terpenuhi maka bukan produktivitas yang didapat tetapi malah penurunan produktivitas yang ada.

9. Manajemen

Manajemen dan komunikasi yang baik, pekerja akan termotivasi dalam bekerja. Oleh karena itu, pimpinan harus bisa memberi contoh yang baik dengan demikian semua pekerja akan termotivasi untuk meningkatkan produktivitasnya.

10. Disiplin kerja

Untuk meningkatkan produktivitas kerja dengan disiplin dari segala bidang, disiplin waktu kerja, disiplin pemakaian bahan baku, dan lain sebagainya akan bisa meningkatkan produktivitas.

11. Kompensasi, gaji atau upah

Pemberian kompensasi yang baik akan meningkatkan kesejahteraan pekerja atau karyawan. Tetapi sebaliknya apabila persahaan tidak pernah memperhatikan pemberian kompensasi kepada karyawan bukan produktivitas naik justru akan turun.

\section{METODOLOGI PENELITIAN}

Metodologi dalam penelitian ini adalah metodologi kuantitatif primer. Data penelitian ini diperoleh melalui kuesioner, observasi dan studi pustaka yang kemudian diolah dengan menggunakan uji statistik. Sampel diambil menggunakan sampling jenuh dimana semua karyawan pada BPJS Ketenagakerjaan Kota Depok menjadi responden, sebanyak 34 responden. Data variabel X (Motivasi Kerja) dan data variabel Y (Produktivitas Kerja Karyawan). Untuk mengetahui korelasi (motivasi kerja) terhadap produktivitas kerja karyawan pada BPJS Ketenagakerjaan Kota Depok maka dilakukan uji statistik dengan menggunakan program SPSS.

\section{HASIL DAN PEMBAHASAN A. Karakteristik Responden}

Dari penelitian yang telah dilakukan, penulis mendapatkan data - data yang akan membantu perhitungan data dalam penelitian ini. Adapun kriteria responden yang disajikan dalam bentuk tabel yaitu berdasarkan jenis kelamin, usia, latar belakang pendidikan, sebagai berikut:

\section{Usia}

Responden yang produktif yaitu pada usia $<25$ tahun sebanyak 6 orang dengan persentase $18 \%$, Responden dengan usia 25-35 tahun sebanyak 8 orang dengan persentase $24 \%$,sedangkan responden usia 35-45 tahun sebanyak 14 orang dengan persentase $41 \%$, dan responden dengan usia $>45$ tahun sebanyak 6 orang dengan persentase $18 \%$.

\section{Jenis Kelamin}

Bahwa responden laki - laki berjumlah sebanyak 15 orang dengan persentase $44 \%$, dan mayoritas responden adalah wanita sebanyak 19 orang dengan persentase $56 \%$.

\section{Latar Belakang Pendidikan}

Responden yang memiliki pendidikan tingkat SMA sebanyak 3 responden dengan persentase $9 \%$, tingkat D3 (Diploma Tiga) sebanyak 6 responden dengan persentase $18 \%$, tingkat $\mathrm{S} 1$ sebanyak 22 responden 
denga persentase $65 \%$, dan tingkat S2 sebanyak 3 responden dengan persentase $9 \%$.

\section{Lama Bekerja}

Bahwa lamanya masa kerja responden pada usia kerja $<5$ tahun sebanyak 13 responden dengan persentase $38 \%$, pada usia kerja 5-10 tahun sebanyak 3 responden dengan persentase $9 \%$, pada usia kerja 10-20 tahun sebanyak 12 responden dengan persentase $35 \%$, dan pada usia kerja > 20 tahun sebanyak 6 responden dengan persentase $18 \%$.

\subsection{Uji Instrumen Penelitian}

Penelitian ini menganalisis dua variabel yaitu yang berkaitan dengan motivasi terhadap kinerja. Kedua variabel tersebut, yaitu variabel bebas $(\mathrm{X})$ adalah motivasi kerja dan variabel terikat (Y) adalah produktivitas kerja karyawan.

Populasi dari data yang dijadikan objek penelitian tugas akhir ini adalah seluruh karyawan pada BPJS Ketenagakerjaan Kota Depok berjumlah 34 responden. Dalam penentuan jumlah besarnya sampel, Penulis menggunakan sampel jenuh dimana semua populasi diambil sebagai sampel.

Dari indikator-indikator yang terdapat di kedua variabel tersebut, penulis membuat kuesioner yang kemudian disebarkan kepada 34 responden.

Kemudian jawaban dari para responden dijadikan masukan oleh penulis untuk menganalisis tingkat kedua hubungan variabel tersebut. Namun, sebelum penulis menganalisis tingkat kedua hubungan variabel tersebut, terlebih dahulu dilakukan uji instrumen dimana butir-butir kuisoner di uji apakah instrumen tersebut valid dan reliabel.

\subsubsection{Uji Validitas}

Pengujian ini dilakukan dengan membandingkan antara $r$ hitung dengan $r$ tabel. Uji validitas dilakukan untuk mengukur sah atau tidaknya indikator kuesioner dari masing-masing variabel.

Uji Validitas dilakukan dengan kriteria $r$ tabel pada tingkat signifikansi 0.05 dengan uji dua sisi (twotailed). Jika nilai positif dan $\mathrm{r}$ hitung $>$ tabel, maka item dapat dinyatakan valid.

Tingkat kevalidan untuk masing-masing indikator atau kuesioner dapat ditentukan, yaitu apabila $r$ hitung $>\mathrm{r}$ tabel $=$ Valid dan $\mathrm{r}$ hitung $<\mathrm{r}$ tabel $=$ Tidak Valid.

Nilai $r$ hitung merupakan hasil korelasi jawaban responden tiap-tiap pernyataan di setiap variabelnya yang dianalisis dengan program SPSS dan output bernama Corrected Item Corelation. Besarnya $\mathrm{r}$ tabel dengan taraf signifikan 5\% adalah 0,339.

Hasil uji validitas untuk variabel motivasi kerja (X) dapat dilihat pada tabel berikut ini:
Tabel 1. Hasil Uji Validitas Motivasi Kerja (X)

\begin{tabular}{ccccc}
\hline \multirow{2}{*}{ Variabel } & Indikator & $\begin{array}{c}\mathbf{r} \\
\text { hitung }\end{array}$ & r tabel & Ket \\
\hline & $\mathrm{X} 1$ & 0,561 & 0,339 & Valid \\
\cline { 2 - 5 } & $\mathrm{X} 2$ & 0,625 & 0,339 & Valid \\
\cline { 2 - 5 } & $\mathrm{X} 3$ & 0,724 & 0,339 & Valid \\
\cline { 2 - 5 } & $\mathrm{X} 4$ & 0,682 & 0,339 & Valid \\
\cline { 2 - 5 } $\begin{array}{c}\text { Kotivasi } \\
\text { Kerja }\end{array}$ & $\mathrm{X} 5$ & 0,620 & 0,339 & Valid \\
\cline { 2 - 5 } & $\mathrm{X} 6$ & 0,615 & 0,339 & Valid \\
\cline { 2 - 5 } & $\mathrm{X} 7$ & 0,510 & 0,339 & Valid \\
\cline { 2 - 5 } & $\mathrm{X} 8$ & 0,414 & 0,339 & Valid \\
\cline { 2 - 5 } & $\mathrm{X} 9$ & 0,751 & 0,339 & Valid \\
\cline { 2 - 5 } & $\mathrm{X} 10$ & 0,694 & 0,339 & Valid \\
\hline
\end{tabular}

Sumber : Hasil Pengolahan SPSS, 2018

Berdasarkan Tabel 1. Hasil Uji Validitas Motivasi Kerja (X) di atas tentang tabel $\mathrm{r}$ uji 2 (dua) arah dengan $\mathrm{N}=34 / \mathrm{df}=32$ taraf kesalahan 5\% diperoleh 0,339. Karena $r$ hitung lebih besar dari $r$ tabel untuk taraf kesalahan $5 \%$ maka dapat disimpulkan indikator motivasi kerja tersebut valid dan dapat dipergunakan untuk penelitian.

Tabel 2. Hasil Uji Validitas Produktivitas $\operatorname{Kerja}(\mathbf{Y})$

\begin{tabular}{ccccc}
\hline \multirow{2}{*}{ Variabel } & Indikator & r hitung & $\begin{array}{c}\text { tabel } \\
\text { Yet }\end{array}$ & Ket \\
\hline & Y1 & 0.730 & 0,339 & Valid \\
\cline { 2 - 5 } & Y2 & 0,749 & 0,339 & Valid \\
\cline { 2 - 5 } & Y3 & 0,344 & 0,339 & Valid \\
\cline { 2 - 5 } & Y4 & 0,411 & 0,339 & Valid \\
\cline { 2 - 5 } $\begin{array}{c}\text { Kerja } \\
\text { (Y) }\end{array}$ & Y5 & 0,732 & 0,339 & Valid \\
\cline { 2 - 5 } & Y6 & 0,587 & 0,339 & Valid \\
\cline { 2 - 5 } & Y8 & 0,491 & 0,339 & Valid \\
\cline { 2 - 5 } & Y9 & 0,736 & 0,339 & Valid \\
\cline { 2 - 5 } & Y10 & 0,747 & 0,339 & Valid \\
\cline { 2 - 5 } & Y11 & 0,697 & 0,339 & Valid \\
\hline
\end{tabular}

Sumber : Hasil Pengolahan SPSS, 2018

Berdasarkan Tabel 2. Hasil Uji Validitas Produktivitas Kerja Karyawan (Y) di atas tentang tabel $\mathrm{r}$ uji 2 (dua) arah dengan $\mathrm{N}=34 / \mathrm{df}=32$ taraf kesalahan 5\% diperoleh 0,339. Karena $r$ hitung lebih besar dari $\mathrm{r}$ tabel untuk taraf kesalahan $5 \%$ maka dapat disimpulkan indikator produktivitas kerja tersebut valid dan dapat dipergunakan untuk penelitian. 


\subsubsection{Korelasi Product Moment}

Setelah di ketahui bahwa butir-butir dalam instrumen valid dan dapat dipercaya, maka langkah selanjutnya adalah untuk mengetahui hubungan antara motivasi terhadap kinerja dengan menggunakan rumus product moment yang terdiri dari koefisien korelasi dan koefisien determinan.

\subsection{Analisis Variabel Motivasi Kerja terhadap Produktivitas Kerja Karyawan \\ 3.2.1. Koefisien Korelasi}

Untuk mengetahui ada tidaknya hubungan antara variabel Motivasi Kerja (X) terhadap Produktivitas Kerja Karyawan (Y) serta untuk mengetahui seberapa besar hitungan dan interpretasi kedua variabel tersebut. Berdasarkan perhitungan kefisien korelasi dengan menggunakan SPSS versi 22 sebagai berikut:

Tabel 3. Uji Koefisien Korelasi

\begin{tabular}{|c|c|c|c|}
\hline \multicolumn{4}{|c|}{ Correlations } \\
\hline & & & Produktivitas \\
\hline & & $\begin{array}{c}\text { Motivasi_ } \\
\text { Kerja }\end{array}$ & Kerja \\
\hline \multirow[t]{3}{*}{$\begin{array}{l}\text { Motivasi_ } \\
\text { Kerja }\end{array}$} & $\begin{array}{l}\text { Pearson } \\
\text { Correlation }\end{array}$ & 1 & ,795** \\
\hline & $\begin{array}{ll}\text { Sig. } & (2- \\
\text { tailed }) & \\
\end{array}$ & &, 000 \\
\hline & $\mathrm{N}$ & 34 & 34 \\
\hline \multirow[t]{3}{*}{$\begin{array}{l}\text { Produktivitas } \\
\text { Kerja }\end{array}$} & $\begin{array}{l}\text { Pearson } \\
\text { Correlation }\end{array}$ &, $795^{* *}$ & 1 \\
\hline & $\begin{array}{ll}\text { Sig. } & (2- \\
\text { tailed) }\end{array}$ & ,000 & \\
\hline & $\mathrm{N}$ & 34 & 34 \\
\hline
\end{tabular}

Sumber : Hasil Pengolahan SPSS, 2018

Berdasarkan Tabel 3. di atas pada koefisien korelasi menunjukan bahwa besarnya pengaruh antara variabel motivasi kerja dan variabel produktivitas kerja adalah 0,795 . Nilai ini mempunyai arti bahwa hubungan kedua variabel tersebut kuat dan mendekati angka 1, dilihat dari tabel II.5 pada pedoman interpretasi koefisien korelasi 0,60-0,799 yang berarti kuat. Koefisien positif $(0,795)$ menunjukan hubungan yang searah, artinya jika motivasi kerja meningkat, produktivitas kerja juga meningkat.

Hubungan antara variabel motivasi kerja dan produktivitas kerja signifikan apabila dilihat dari angka signifikan (sig.) sebesar $0,000<0,05$. Berdasarkan ketentuan, jika angka signifikan $<0,05$ hubungan antara kedua variabel tersebut signifikan, menurut (Sugiyono, 2014).

\subsubsection{Uji Koefisien Determinasi}

Setelah ditemukan hasil koefisien korelasi kemudian selanjutnya adalah mencari determinasi. Koefisien determinasi digunakan untuk mengetahui seberapa besar kemampuan Variabel Independen (Motivasi) menjelaskan variabel Dependen (Produktivitas) yang dilihat melalui $R$ Square.

Tabel 4. Uji Koefisien Determinasi

\begin{tabular}{lcccc}
\hline \multicolumn{5}{c}{ Model Summary } \\
\hline Model & $\mathrm{R}$ & Square & $\begin{array}{c}\text { Adjusted R } \\
\text { Square }\end{array}$ & $\begin{array}{c}\text { Std. Error of } \\
\text { the Estimate }\end{array}$ \\
\hline 1 &, $795^{\mathrm{a}}$ &, 632 &, 620 & 2,554 \\
\hline \multicolumn{2}{l}{ a. Predictors: (Constant), Motivasi }
\end{tabular}

Sumber: Pengolahan Data SPSS 22, 2018

Dari Tabel 4. di atas pada hasil koefisien determinasi diatas dapat diketahui bahwa nilai ( $R$ Square) sebesar 0,632 atau $63,2 \%$ artinya motivasi kerja mempengaruhi produktivitas kerja sebesar 63,2\% dan sisanya yaitu $36,8 \%$ dipengaruhi oleh faktor lain yang belum diteliti.

\subsubsection{Uji Persamaan Regresi}

Uji Persamaan Regresi digunakan untuk mengetahui angka konstan dan uji hipotesis signifikan koefisien regresi. Berdasarkan perhitungan persamaan regresi menggunakan SPSS versi 22 sebagai berikut:

Tabel 5. Hasil Persamaan Regresi

\begin{tabular}{|c|c|c|c|c|c|}
\hline \multicolumn{6}{|c|}{ Coefficients $^{\mathbf{a}}$} \\
\hline \multirow[b]{2}{*}{ Model } & $\begin{array}{r}\text { Unstand } \\
\text { Coeffi }\end{array}$ & $\begin{array}{l}\text { ardized } \\
\text { cients }\end{array}$ & $\begin{array}{l}\text { Standardized } \\
\text { Coefficients }\end{array}$ & \multirow[b]{2}{*}{$\mathrm{t}$} & \multirow[b]{2}{*}{ Sig. } \\
\hline & $\mathrm{B}$ & $\begin{array}{l}\text { Std. } \\
\text { Error }\end{array}$ & Beta & & \\
\hline 1 (Constant) & 6,883 & 5,335 & & 1,290 & ,206 \\
\hline Motivasi &, 831 &, 112 &, 795 & 7,406 &, 000 \\
\hline \multicolumn{6}{|c|}{ a. Dependent Variable: Produktivitas } \\
\hline
\end{tabular}

Berdasarkan Tabel 5. di atas tentang hasil uji persamaan regresi tingkat signifikan sebesar $0,00<$ 0,05 maka $\mathrm{H}_{0}$ ditolak dan $\mathrm{H}_{1}$ diterima. Persamaan regresinya sebagai berikut:

$\mathrm{Y}=\mathrm{a}+\mathrm{bx}$

$\mathrm{Y}=6,883+0,831$

Keterangan:

$\mathrm{Y}=$ Produktivitas kerja

$\mathrm{X}=$ Motivasi kerja

Persamaan tersebut dapat dijelaskan:

Jika motivasi kerja (X) mengalami kenaikan 1 satuan maka akan menaikan produktivitas kerja karyawan (Y) sebesar 0,831. Hal ini menunjukkan bahwa ada pengaruh positif atau searah antara variabel motivasi kerja (X) terhadap produktivitas kerja karyawan (Y) pada BPJS Ketenagakerjaan Kota Depok. Oleh karena itu, persamaannya menjadi $\mathrm{Y}=6,883+0,831 \mathrm{X}$ 


\section{KESIMPULAN}

Kesimpulan yang dapat ditarik dari penelitian ini adalah:

1. Hasil penelitian yang penulis dapat dari uji koefisien korelasi diperoleh hasil sebesar 0,795 yang menunjukkan adanya pengaruh yang kuat antara motivasi kerja terhadap produktivitas kerja karyawan pada BPJS Ketenagakerjaa Cabang Depok.

2. Untuk mengetahui seberapa besar pengaruh antara motivasi kerja terhadap produktivitas kerja, maka digunakan teknik perhitungan koefisien determinasi diperoleh hasil sebesar 0,632 atau sama dengan $63,2 \%$ artinya motivasi kerja mempengaruhi produktivitas kerja sebesar $63,2 \%$ dan sisanya (100\%-63,2\%) yaitu $36,8 \%$ dipengaruhi oleh faktor lain.

3. Berdasarkan perhitungan persamaan regresi dapat diperoleh persamaan $\mathrm{Y}=6,883+0,831$ artinya jika motivasi kerja mengalami kenaikan $1 \%$ maka akan menaikan produktivitas kerja karyawan sebesar 0,831. Hal ini menunjukkan bahwa ada pengaruh positif atau searah antara variabel motivasi kerja terhadap produktivitas kerja karyawan pada BPJS Ketenagakerjaan Cabang Depok. Oleh karena itu, persamaannya menjadi $\mathrm{Y}=6,883+0,831 \mathrm{X}$.

\section{REFERENSI}

Ainnisya, R. N., \& Susilowati, I. H. (2018). Pengaruh Penilaian Kinerja Terhadap Motivasi Kerja Karyawan Pada Hotel Cipta Mampang Jakarta Selatan, II(1), 133-140. https://doi.org/10.31294/WIDYACIPTA.V2I1. 2989

Hanif, A. (2018). Menggunakan Stepwise Linear Regression Untuk Menentukan Faktor Yang Mempengaruhi Produktivitas Tenaga Kerja, 5(1), 73-80.

Hasibuan, M. S. P. (2016). Manajemen Sumber Daya Manusia Edisi Revisi. Jakarta: PT. Bumi
Aksara.

Lestari, N. E. P. (2018). Pengaruh Motivasi,Kompetensi, Kepemimpinan dan Lingkungan Kerja Terhadap Kinerja Karyawan Pada PT. Geotech Sistem Indonesia. Moneter, 5(1), 99-104.

Mangkunegara, A. P. (2015). Sumber Daya Manusia Perusahaan Cetakan Kedua Belas. Bandung: Remaja Rosdakarya.

Mulyadi. (2015). Akuntansi Biaya, Edisi 5. Yogyakarta: Sekolah Tinggi Ilmu Manajemen YKPN.

Nurmalasari. (2016). Dampak Kompensasi Terhadap Peningkatan Produktivitas Kerja Karyawan Pada PT. Pasifik Jaya Mandiri Pontianak, 4.

Siswanto, B. (2014). Manajemen Tenaga Kerja Rancangan dalam Pendayagunaan dan Pengembangan Unsur Tenaga Kerja. Bandung: Sinar Baru.

Sugiyono. (2014). Metode Penelitian Pendidikan Pendekatan Kuantitatif, Kualitatif dan $R \& D$. Bandung: Alfabeta.

Sutrisno, E. (2016). Manajemen Sumber Daya Manusia. Jakarta: Prenadamedia Group.

Widodo, S. E. (2015). Manajemen Pengembangan Sumber Daya Manusia. Yogyakarta: Pustaka Pelajar.

\section{PROFIL PENULIS}

Nurlaela Eva Puji Lestari adalah Dosen di Universitas Bina Sarana Informatika dengan Program Studi Administrasi Bisnis. Penulis lahir di Tegal pada tanggal 15 April 1990 di Tegal. Mendapat gelar S.E pada Universitas BSI Bandung yang lulus pada tahun 2014. Tahun 2016 mendapat gelar S2 Magister Manajaemen dari Universitas Budi Luhur pada bidang Ilmu Manajamen dengan konsentrasi Manajemen Sumber Daya Manusia. 